\title{
EFFECT OF AUDIT QUALITY ON MARKET PRICE PER SHARE OF QUOTED DEPOSIT MONEY BANKS (DMBS) IN NIGERIA
}

\author{
ISAH, Mansur ${ }^{1}$; FASUA, Kayode Olushola ${ }^{2}$; Ugoh, Timothy Terver ${ }^{3}$ and \\ OJO, Lukman Olatunji ${ }^{4}$ \\ ${ }^{1}$ Department of Accounting, Nasarawa State University, Keffi \\ ${ }^{2}$ Nigerian College of Accountancy, Kwall, Jos \\ ${ }^{3}$ Department of Accounting, Nasarawa State University, Keffi \\ ${ }^{4}$ Department of Accounting, Nasarawa State University, Keffi
}

DOI: 10.46609/IJSSER.2020.v05i12.014 URL: https://doi.org/10.46609/IJSSER.2020.v05i12.014

\begin{abstract}
This study is used to determine whether Audit Quality has any significant effect on Market price per Share of companies in Nigeria. Archival data were extracted from annual reports of 14 deposit money banks quoted on the Nigerian Stock Exchange (NSE) between 2012 and 2018. Audit Quality was estimated using Audit Firm Size, Audit Fees, Auditor Tenure and Audit industry specialization. Market Price per Share (MPS) was derived directly from CSCS Cash Craft. The study adopted and ex post facto research design and relied on signaling theory. Multiple regression analyses were conducted on the data. The results of the tests show that Audit Quality exerts significant influence on the MPS of quoted DMBs in Nigeria. Specifically, the study found that audit firm size, audit tenure and auditors' industry specialization have significant effect on audit quality while audit fees have insignificant effect on market price per share of quoted DMBs in Nigeria. In order to improve the quality of banks in Nigeria, the study recommend that regulatory agencies - professional accountancy bodies, Financial Reporting Council of Nigeria, the National Assembly, and Securities and Exchange Commission should issue authoritative standard and framework for audit quality.
\end{abstract}

Keywords: Audit quality, market price per share, deposit money banks, Nigeria.

\section{INTRODUCTION}

High-quality external auditing is a central component of a well-functioning capital market. Companies with a reputation for credible financial reporting are likely to change auditors when their audit quality is questioned to avoid capital market consequences of unreliable financial reporting (Hennes, Leone \& Miller, 2012). The performance of independent auditors is deemed fundamental to the functioning of the financial and capital markets based on the assumption that, by issuing an opinion on the reliability of accounting information, it contributes to a business 


\section{International Journal of Social Science and Economic Research}

ISSN: $2455-8834$

Volume:05, Issue:12 "December 2020"

environment characterized by trust and credibility (Newman, Patterson \& Smith, 2005; Ojo, 2008; Zagonov, 2011). It also, goes a long way in solving the problem of information asymmetry between management and users. However, with the corporate scandals at the start of the century, characterized by fraud and accounting manipulation, much has been discussed about the scope of responsibilities of auditors, given that the opinion on financial statements has not changed.

Also, the value of a company's shares has been shown to represent the value of its future earnings (Lev, 1989) and this explains why investors in a company have vital interest in the earnings reports. Consequently, company managers use certain strategies to deliberately manipulate company earnings in order to match a predetermined target and involve the planning and execution of certain activities that manipulate or smooth income, achieve high earnings level and sway the company's stock price (Schipper, 1989; Healy \& Wahlen, 1999). Earnings manipulation activities may occur because managers have flexibility in making accounting or operating choices, or because managers are trying to convey private information to financial statement users. The conveyance of private information may be done to give stakeholders information not otherwise available so that they can adjust their expectations appropriately. Careful release of such information may have effect on the earnings and the share price for the company. If the information conveys significant value relevance to analysts and other users of financial statements, they may also adjust earnings estimates and share prices for other companies in the industry. This may positively influence the company revealing the information to experience positive impact on its share prices because it is perceived as having a higher quality of earnings.

Basically, the quality of reported earnings and the ability of audit quality to effectively constrain earnings misrepresentation and financial statement manipulations of companies across the world and Nigeria in particular, have become considerably questionable due to recent corporate accounting scandals (Badawi, 2008; Enofe, 2010). Differences in Audit Quality result in variations in the credibility of auditors and the reliability of the earnings reports of companies. The corporate financial scandals at the start of the century pose a great challenge to the veracity, credibility, utility or value relevance of the audit function. In Nigeria, corporate scandals include the cases of Cadbury Nigeria Plc and African Petroleum (AP) (Okolie \& Agboma, 2008); Savannah Bank and African International Bank (Odia, 2007); Wema Bank, Nampak, Finbank and Spring Bank (Adeyemi and Fagbemi, 2010); and more recently Intercontinental Bank Plc., Bank PHB; Oceanic Bank Plc. and AfriBank Plc. These are known publicly reported cases that resulted in misleading financial reports. There is therefore, a concern about the quality of accounting income and its relationship with the quality of the auditing process which has been observed to increase over time following the periodical clusters of business failures, frauds, and the litigations. The issue is whether these corporate collapses are not the outcome of poor audit 
International Journal of Social Science and Economic Research

ISSN: 2455-8834

Volume:05, Issue:12 "December 2020"

quality and the inability of the audit function to arrest earnings misreporting and financial misstatements.

There also, exists in literature few studies to the best of researchers' knowledge investigating the effect of audit quality on market performance in Nigeria (Okoli \& Izedonmi, 2014; Okoli, 2014; Ugwunta, Ugwuanyi \& Ngwa, 2018). However, none of these domestic studies were carried out in the banking sector which has been a focus of fraudulent reporting over the years. This current study will fill the gaps in variable differences, timing differences and sectorial peculiarities existing in literature, by empirically assessing the effect of Audit Quality (explained by audit fees, audit tenure, audit firm size and auditors' industry specialization) on market performance (measured by market price per share) of quoted deposit money banks in Nigeria. (The study controlled for bank size and leverage).

This study is based on the following hypothesis:

$\mathrm{HO}_{1}$ Audit fees have no significant effect on market performance of quoted deposit money banks in Nigeria.

$\mathrm{HO}_{2}$ Audit tenure have no significant effect on market performance of quoted deposit money banks in Nigeria.

$\mathrm{HO}_{3}$ Audit firm size have no significant effect on market performance of quoted deposit money banks in Nigeria.

$\mathrm{HO}_{4}$ Auditor industry specialization have no significant effect on market performance of quoted deposit money banks in Nigeria.

\section{LITERATURE REVIEW}

\section{Audit Quality}

There has been controversy over the years as to what constitute the most acceptable definition of audit quality. The classic definition of audit quality that is cited by most audit researchers is that of DeAngelo (1981). He defined audit quality as the market-assessed joint probability that the auditor discovers an anomaly in the financial statements, and reveals it. Audit quality measures based on this definition is indirect method of measuring audit quality with the aid of indicators. However, DeAngelo's definition is the most cited definition of audit quality, the dilemma is that audit quality according to this definition, it cannot be observed let alone measured.

Seyyed (2013) provided further explanation that, audit quality could be a function of the auditors' ability to detect material misstatements and reporting the errors, both definitions laid emphasize on two of the most significant aspects of audit quality, specifically auditor ability or 


\section{International Journal of Social Science and Economic Research}

ISSN: $2455-8834$

Volume:05, Issue:12 "December 2020"

auditor effort, and auditor independence. Therefore, this flow of definitions is mainly about the audit quality. Besides, other set of definitions centered on the degree to which the audit conforms to applicable auditing standards.

Government Accountability Office (2003) viewed a high-quality audit as audit -in accordance with generally accepted auditing standards to provide reasonable assurance that the audited financial statements and related disclosures are presented in accordance with generally accepted accounting principles and are not materially misstated whether due to errors or fraud. Hope and Langli(2007) viewed audit quality as when the auditor do his work with higher degree of independence and objectivity on the one hand and define auditor independence as the auditor objectivity and ability to with stand client pressure on the other hand. This pressure according to the $m$ includes monetary and non-monetary issues that make auditor comply with management desire rather than his professional judgment. Titman and Trueman(1986) on the other hand defined audit quality as the accuracy of the information reported by auditors. Audit quality in this regard comprises the ability of an auditor to detect a breach (auditor competence) and the willingness to report such a breach (auditor independence).This study will align with the definition by DeAgelo (1981).

Basically, there are certain fundamental characteristics to watch out for when audit quality is a subject of discussion. This attributes for examples include audit fees, firm size, tenure, industry specialization etc. This implies that audit quality is prominent where these characteristics can be identified.

\section{Audit Fees}

Audit fees can be explained to be the amount charged by the auditor for an audit assignment carried out. That is, the amount charged by the auditor for any work done in order to express opinion on the true and fair state of affairs or position of the client's enterprise. Iskak (1999 in Suharli \& Nurlaelah, 2008) described audit fee as the fee charged by a public accountant to the client for the financial audit services. This is in accordance with the opinion of The Securities and Exchange Commission, Final Rule (in Yuniarti, 2011) that the audit fee is the fees paid for annual audits and reviews of financial statements for the most recent fiscal year. The amount of audit fee can vary depending on the complexity of services, assignment risk, the cost structure of Public Accountants Firm, the required level of expertise, and other professional considerations.

\section{Audit Firm Size}

On the other hand, the difficulty in measuring audit quality has led many researchers to use audit firm size as a surrogate. Large audit firms are assumed to perform more powerful tests. As a consequence, larger audit firms are more likely to be associated with more precise information 


\section{International Journal of Social Science and Economic Research}

ISSN: $2455-8834$

Volume:05, Issue:12 "December 2020"

than are smaller audit firms, all else being equal (Beatty, 1989; Titman \& Trueman, 1986). Analytical research has suggested that audit firm size and audit quality are positively related. For example, DeAngelo, (1981) proposes that larger firms provide higher-quality audits because larger audit firms have fewer incentives to compromise their standards to ensure retention of clients in comparison with smaller firms. Similarly, Dopuch and Simunic (1982) argues that audit quality is a function of the number and extent of audit procedures performed by the auditor and that larger firms have more resources with which to conduct tests. Moore and Scott (1989) demonstrate analytically that audit firm size and the extent of audit work are positively related. Further, if audit firm size and audit quality are positively related, we would expect to find larger differences between forecasted and reported incomes for companies audited by large auditors than for companies audited by small auditors, after controlling for client characteristics such as risk.

\section{Audit Tenure}

Similarly, Audit tenure is the agreed period of engagement between the auditor and client (Hartadi, 2009). The issue of audit tenure is usually linked to auditor independence. Research conducted by Ghosh and Moon (2003), shows that audit quality increases as audit tenure increases. This result is however contrary to the results of a research conducted by Indah (2010), which reveals that as the length of auditor-client relationship increases; there could be decrease in the level of audit quality, because too long auditor-client relationship impairs auditor's independence. Furthermore, the audit quality decreases as the auditor-client relationship lengthen (Deis \& Giroux, 1992). However, the study involving going-concern report in the US suggest that audit reporting failures are significantly higher in the first few years of auditor-client relationship (Geiger \& Raghunandan, 2002). According to Chen (2008), audit firm tenure as well as audit partner tenure, affects quality of reported earnings.

\section{Auditors Industry Specialization}

Also, industry specialist auditors are auditors who have gained great training and experience concentrated in a specific industry. Solomon et al. (1999) find that industry specialist auditors have more accurate non-error frequency knowledge than non-industry specialists. Owhoso, Messier and Lynch (2002) suggest that industry specialists can more effectively detect seeded errors in staff work papers during the audit review process. Low (2004) finds that auditors' industry specialization improves their audit risk assessments. Hammersley (2006) finds that matched specialists (i.e., specialists working in their industry) develop more complete problem representations about the seeded misstatement when they receive partial- or full-cue patterns than when they receive no-cue patterns, whereas mismatched specialists are not able to develop more complete problem representations even when they receive full-cue patterns. These behavioral 


\section{International Journal of Social Science and Economic Research}

ISSN: $2455-8834$

Volume:05, Issue:12 "December 2020"

auditing studies suggest that auditor industry specialization can enhance the effectiveness of auditors' work as a result of their greater industry-specific knowledge.

\section{Market Price per share}

Market price per share (MPS)is the price thata stock can be readily purchased or sold in the current market place (Nehe \& Bajaj, 2017). It is the "going price" of a share of stock. The MPS may vary everyday due to changes and fluctuations in the stock market and economy. MPS is affected by not only the economy as a whole but also investors' perceptions and expectations (Hemadivya \& Rama, 2013).

\section{Empirical Review}

Okoli and Izedonmi (2014) determined the impact of audit quality on market value per share of companies of 57 companies quoted on the Nigerian stock exchange (NSE) between 2006 and 2011. Audit quality was estimated using audit firm size, audit fees auditor tenure and audit client importance. Market per share (MPS) was derived directly from CSCS Cash-Craft. Multiple regression analyses were conducted on the data. The result of the test show that audit quality exerts significant influence on the MPS of quoted companies in Nigeria.

Okoli (2014) examined the influence of audit firm size on market value per share of companies in Nigeria based on a data of 342 companies-year observations from the NSE and applying audit firm size as a measure. Comprehensive multivariate analyses were conducted on archival data covering 2006-2011. The result showed that audit firm size exerts significant relationship and significantly influences market price per share of companies in the sample.

Ugwunta, Ugwuanyi and Ngwa (2018) examined the effect of audit quality on share prices of Nigerian oil and gas firms using the regression and covariance analyses. Findings from the regression anlysis suggests that the composition of the audit committee and auditor type has significant effect on the market prices of quoted firms. The covariance analysis suggests that while auditor type (BIG4/NONBIG4), auditor independence, and composition of the audit committee have a positive and significant relationship with market price of shares, tenure of external auditors has a negative relationship with the market price of shares. The implication of the findings is that audit quality will enhance reported earnings and hence the share market prices.

Elewa and El-Haddad (2019) examined the effect of audit quality on firm performance. It used financial statements of non-financial firms listed as EGX 100. The population studied consists of thirty non-financial firms. The study covered a five-year period 2010-2014. It applies panel data analysis. Independent Variables are Auditor Experience (measured by Big-4) and Auditor Independence (measured by auditor Rotation ROT). Dependent Variables are Return on Assets 


\section{International Journal of Social Science and Economic Research}

ISSN: $2455-8834$

Volume:05, Issue:12 "December 2020"

ROA and Return on Equity ROE. In accordance with the Random Effect Model results, BIG 4 and ROT the study found insignificant impact on the ROA and ROE of the firm.

Ugwunta, Ugwuanyi and Ngwa (2018) examined the effect of audit quality on share prices of Nigerian oil and gas firms using the regression and covariance analyses. Findings from the regression anlysis suggested that the composition of the audit committee and auditor type has significant effect on the market prices of quoted firms. The covariance analysis suggested that while auditor type (BIG4/NONBIG4), auditor independence, and composition of the audit committee have a positive and significant relationship with market price of shares, tenure of external auditors has a negative relationship with the market price of shares. The import of the findings is that audit quality will enhance reported earnings and hence the share market prices.

Tyokoso, U-ungwa and Ojonimi (2017) examined the effect of audit quality, represented by audit firm size, auditor tenure, client importance and auditor specialization on Wthe performance, represented by Tobins Q, of listed Deposit Money Banks (DMBs) in Nigeria. Secondary data extracted from annual report and accounts of 8 DMBs was analyzed using panel multiple regression technique. Result of Hausman specification test suggests that the Ordinary Least Square (OLS) regression result was most appropriate for the dataset. The regression result indicates that auditor tenure has significant positive effect on Tobins $Q$ of DMBs in Nigeria. In contrast, client importance has a significant negative relationship with Tobins $\mathrm{Q}$ while audit firm size and auditor specialization respectively have insignificant positive and negative effect on Tobins Q of DMBs in Nigeria.

Okoli and Izedonmi (2014) determined the impact of audit quality on market value per share of companies of 57 companies quoted on the Nigerian stock exchange (NSE) between 2006 and 2011. Audit quality was estimated using audit firm size, audit fees auditor tenure and audit client importance. Market per share (MPS) was derived directly from CSCS Cash-Craft. Multiple regression analyses were conducted on the data. The result of the test show that audit quality exerts significant influence on the MPS of quoted companies in Nigeria.

Okoli (2014) examined the influence of audit firm size on market value per share of companies in Nigeria based on a data of 342 companies-year observations from the NSE and applying audit firm size as a measure. Comprehensive multivariate analyses were conducted on archival data covering 2006-2011. The result showed that audit firm size exerts significant relationship and significantly influences market price per share of companies in the sample.

Musa and Shehu (2014)examined the impact of audit quality on financial performance of quoted firms in Nigeria. The study is descriptive in nature and the correlation and ex-post facto designs were adopted in carrying out this research. Data were obtained basically from the published annual reports and accounts, and notes to the financial statements of the four firms that represent 


\section{International Journal of Social Science and Economic Research}

ISSN: $2455-8834$

Volume:05, Issue:12 "December 2020"

the sample of the study. The data collected were quantified and presented in tables. Multiple regression analysis using the SPSS Version 15.0 was employed in analyzing the data and testing the stated hypotheses. The results of the findings showed that auditor size and auditor independence have significant impacts on the financial performance of quoted cement firms in Nigeria.

Bouaziz (2012), examined the relationship between auditor size and financial performance on a sample of 26 Tunisian firms listed on the Tunis Stock Exchange. The result shows that auditor size has an important impact on the financial performance of firms in terms of return on assets and return on equity.

Anderson and Verma (2012), examined the relationship between auditor size, auditor tenure and audit firm rotation using a probit model which they developed. The data they collected from 2,148 listed Asian companies shows that big audit firms provide high quality audit because big audit firms are more conservative than non-big audit firms. They also discovered that national level factors have a strong influence on audit quality. Auditor tenure is associated with impaired audit quality and audit firm rotation can help promote audit quality.

\section{Supported Theories}

Essentially, agency theory, signaling theory, and auditors' theory of inspired confidence justify the key function of auditing as a mechanism for mitigating information asymmetries among related parties. For the purpose of this study only signaling theory is discussed. The study is anchored on signaling theory.

\section{Signaling Theory}

Signaling through auditor choice stands on the agency theory, and is a manner by which managers and/or directors may impart to the market additional information about their company and their own behaviour. Signaling theory suggests that companies with good performance use financial information disclosure to send signals to the market. Craven and Marston (1999), show that firms will attempt to accept the same level of disclosure as similar firms operating in the same industry since if a firm does not keep up with the same level of disclosure as others, it may be perceived by stakeholders that it is hiding bad news or negative information. As the types of financial statements produced have become standardized, potential information differentiation that a company can use to send a signal to the market through its financial statements is reduced. Companies are thus provided an incentive to signal, other than through transparency in their notes to the accounts and other voluntary disclosures, through their choice of auditor. Moreover, even voluntary disclosures that may be used as signals achieve enhanced credibility in the presence of a quality auditor. A high-quality audit sends a signal to the market that the financial 
International Journal of Social Science and Economic Research

ISSN: 2455-8834

Volume:05, Issue:12 "December 2020"

statements are more credible than those audited by lower quality auditors. The market perceives audit firm size and specialist auditors to be of a higher quality than others and rewards (punishes) companies with larger improvements (or falls) in share prices accordingly (Teoh \& Wong, 1993; Krishnan \& Yang, 1999; Menon \& Williams, 1994).

Furthermore, signaling theory does not actually require higher audit quality, it merely needs the market to believe that Top Tier firms are associated with higher audit quality because of the fee premiums they are able to command (Moizer, 1997). It has been shown that the market's perception of the quality of the company's auditor influences that company's share price. As such, directors and management may want to signal to the stakeholders that their interest is being well monitored. Therefore, signaling should, theoretically, affect the demand for audit quality over and beyond the monitoring function alone. The positive Signal of transparency and credibility it sends to the market and the assurance it provides to stakeholders about the quality of earnings performance disclosures suggests a positive association between MPS and audit quality.

\section{METHODOLOGY}

The study adopts a descriptive ex post facto research design. The study covers a period of 2012 to 2018. Population includes all the 14 Deposit Money Banks (DBMs) quoted on the floors of the Nigerian stock exchange throughout the period of the study. Secondary data was extracted from the annual accounts of banks for the period of the study. The study employs the use of multiple regression technique to analyse the data with the aid of STATA version13. The model of the study is stated below.

MPSit $=\beta 0+\beta 1 \mathrm{AFit}+\beta 2 \mathrm{AISit}+\beta 3 \mathrm{AT}_{\mathrm{it}}+\beta 4 \mathrm{AFSt}+\beta 5 \mathrm{BKZit}+\beta 6 \mathrm{LEVit}+e_{i t}$

Where:

MPS= Market Price Per Share

$\mathrm{AF}=$ Audit Fees

$\mathrm{AI}=$ Auditor industry Specialization

$\mathrm{AT}=$ Audit Tenure

$\mathrm{AFS}=$ Audit Firm Size

$\mathrm{BKZ}=$ Bank Size

$\mathrm{LEV}=$ Leverage

$\beta 0=$ is theintercept 
$\beta 1-\beta 4=$ arethe parameters estimate or coefficients in equation

$\mu=$ error

\section{Measurement of Variables}

\section{Derivation of Market Price per Share (MPS)}

Market Price per share (MPS) of each of the 14 listed deposit money banks will be obtained directly from www_cashcraft_com as at the end of the year. "Cash craft" is a unit of the Central Securities Clearing System (CSCS) in Nigerian Stock Exchange.

\section{Estimation of Audit Quality}

The major proposition of this study will be that market performance of deposit money banks in Nigeria depends on audit quality and we will treat the individual variable effects as well as the effects of using all the audit quality attributes together in line with Heninger (2001), Ebrahim (2001), Piot and Janin, 2005, and Gerayli et al (2011). Using a number of explanatory variables after controlling for the effects of exogenous variables on the dependent variable as authenticated by Thierauf and Klekamp (1975: 20) who posit that "a general model which will be representative of a system under study takes the form of $E=f\left(X_{1}, X_{2}, \ldots X_{n}, Y_{1}, Y_{2}, \ldots Y_{n}\right)$ )". Where: $\mathrm{E}=$ objective function; $\mathrm{X}_{1}, \mathrm{X}_{2} \ldots \mathrm{X}_{\mathrm{n}}=$ system variables that are subject to control (controllable variables); $\mathrm{Y}_{1}, \mathrm{Y}_{2} \ldots \mathrm{Y}_{\mathrm{n}}=$ system variables that are not subject to control (uncontrollable variables).

\section{Control Variables:}

Certain exogenous factors may impact on market price per share of a company. Such control variables to be examined in this study will include; Leverage (LEV), and Bank Size (FZ).

The measurement and construct validity of all the variables and the specific review of the various proxies for estimating audit quality are contained in table 1 below.

\section{TABLE1: MEASUREMENT OF VARIABLES/ VALIDITY}

\begin{tabular}{|l|l|l|l|l|l|}
\hline S/N & Variables & Definitions & Type & Measurement & $\begin{array}{l}\text { Construct validity } \\
\text { source }\end{array}$ \\
\hline 1 & MPS & $\begin{array}{l}\text { Market Price } \\
\text { per share }\end{array}$ & Dependent & $\begin{array}{l}\text { Will be obtained } \\
\text { directly from CSCS } \\
\text { at } \\
\text { www_cashcraft_com }\end{array}$ & $\begin{array}{l}\text { Ohlson, (1995); Amir } \\
(1996) ; \quad \text { Collins, } \\
\text { maydew and Weiss } \\
(1997) .\end{array}$ \\
\hline
\end{tabular}


International Journal of Social Science and Economic Research

ISSN: 2455-8834

Volume:05, Issue:12 "December 2020"

\begin{tabular}{|c|c|c|c|c|c|}
\hline 2 & AFS & $\begin{array}{ll}\text { Audit } & \text { Firm } \\
\text { Size } & \end{array}$ & Independent & $\begin{array}{l}\text { Dichotomous: ' } 1 \text { ' if } \\
\text { company is audited } \\
\text { by a Big4, ' } 0 \text { ' } \\
\text { otherwise }\end{array}$ & 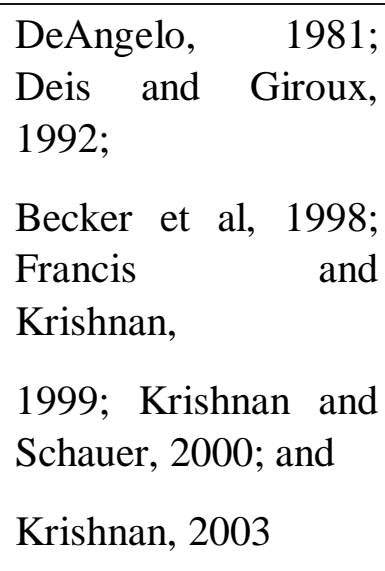 \\
\hline 3 & $\mathrm{AF}$ & $\begin{array}{l}\text { A measure of } \\
\text { Auditor } \\
\text { Independence }\end{array}$ & $"$ & $\begin{array}{l}\text { Natural Log of the } \\
\text { Audit Fees Paid by } \\
\text { the company. }\end{array}$ & $\begin{array}{l}\text { Palmrose, } \\
\text { Copley (1998), } \\
\text { Frankel et al, 2002; } \\
\text { Li \& Lin, 2005; } \\
\text { Gerayli et al, 2011 }\end{array}$ \\
\hline 4 & AT & Audit Tenure & $"$ & $\begin{array}{l}\text { Length of auditor- } \\
\text { client relationship: } \\
\text { ' } 1 \text { ' if } 3 \mathrm{yrs}^{+} \& \text { ' } 0 \text { ' if } \\
\text { otherwise. }\end{array}$ & $\begin{array}{l}\text { Heninger ( 2001); } \\
\text { Ebrahim (2001) }\end{array}$ \\
\hline 5 & AIS & $\begin{array}{l}\text { Auditor } \\
\text { industry } \\
\text { specialization }\end{array}$ & $"$ & $\begin{array}{l}\text { Measured by } \\
\text { dichotomous } \\
\text { variable } 1 \text { for the } \\
\text { companies audited } \\
\text { by industry } \\
\text { specialist auditors } \\
\text { and } 0 \text { for non- } \\
\text { specialist auditors. }\end{array}$ & $\begin{array}{l}\text { Zhou and Elder } \\
\text { (2001); Krishnan and } \\
\text { Yang 2003). }\end{array}$ \\
\hline 6 & BKZ & Bank Size & $"$ & $\begin{array}{lr}\text { Natural } & \log \text { of } \\
\text { company } & \text { Total } \\
\text { Assets } & \end{array}$ & $\begin{array}{l}\text { Bauwhede et al, } \\
2000 \text {; Gerayli et al, } \\
2011\end{array}$ \\
\hline 7 & Lev. & Leverage & $"$ & $\begin{array}{l}\text { TotalDebts } \\
\text { Equity }\end{array}$ & $\begin{array}{l}\text { Becker et al (1998), } \\
\text { Watts \& } \\
\text { Zimmerman, (1986) }\end{array}$ \\
\hline
\end{tabular}


International Journal of Social Science and Economic Research

ISSN: 2455-8834

Volume:05, Issue:12 "December 2020"

\section{RESULTS AND DISCUSSIONS}

This section discussed the results obtained from the analysis of the study using multiple regression technique with the aid of STATA 13. The section presented the descriptive statistics, the correlation matrix, regression diagnostic test (Variance Inflation Factor and test heteroscedasticity), hausman specification test and the regression results.

\section{Descriptive Statistics}

Descriptive statistics explains the behavior of data used for analysis. In this study, the descriptive statistics presented the result of the mean, standard deviation, minimum and maximum as well as the number of observations. The result is as presented below.

Table 1: Descriptive Statistics

\begin{tabular}{|l|l|l|l|l|l|}
\hline Variable & Obs & Mean & Std. Dev. & Min & Max \\
\hline SP & 91 & 5.9791 & 5.8317 & .54 & 34.45 \\
\hline AUDFSZ & 91 & .7362 & .4430 & 0 & 1 \\
\hline FEES & 91 & 4.3054 & .7429 & .5986 & 7.6789 \\
\hline AUTEN & 91 & .5494 & .5003 & 0 & 1 \\
\hline AUS & 91 & .6373 & .4834 & 0 & 1 \\
\hline FS & 91 & 7.6196 & 1.5913 & 4.5782 & 11.6274 \\
\hline LEV & 91 & .4196 & .1480 & .1238 & .7237 \\
\hline
\end{tabular}

\section{Source: STATA OUTPUT, 2019}

The table 1 describes the behavior of data used for the analysis. From the table 1 it can be observed the total banks financial year observations are 91 . The result showed an average share price of 5.9791 and a corresponding standard deviation of 5.8317. This signified that the average shares price for the banks within the period stood at six naira and the value of the standard deviation showed that the difference between the shares price of banks with the period significantly differ. The minimum and maximum value of .54 and 34.45 depicted that the lowest and highest banks shares were sold within the period covered by the study. The table 1 also, that an average of $73 \%$ of the companies used Big4 auditors and value of SD shows that there is no 
International Journal of Social Science and Economic Research

ISSN: 2455-8834

Volume:05, Issue:12 "December 2020"

much deviation from the data. Again, the result showed that atleast one bank used Big4 auditors yearly within period of the study. Audit fees as indicated by the table 1 above showed an average of 4.3054 million naira. The minimum indicated approximately six hundred thousand while the maximum showed about 7.68 million approximately. The result for audit tenure displayed a mean of .5494 and corresponding SD of .5005. This implied that an average of $55 \%$ of the banks had auditors with tenure more than three years and this is confirmed by the value of SD. The result also, evidenced that atleast the auditors spent above a year on their engagements. The table 1 again, presented results on auditors' industry specialization with .6373 as the mean and an SD of .4838 meaning about $64 \%$ of the auditors used industry specialist auditors. The results also, showed that in every year, atleast one bank used industry specialist auditors.

This study controlled for the effect of exogenous variables and the variables controlled for were firm size and leverage. The result from table 1 showed an average firm size of 7.6 trillion and the value of SD of 1.5913 which implied that the size of the banks varied from one another. The minimum banks size was 4.5782 trillion while the highest was 11.6274 trillion within the period covered by the study. Leverage as evidenced by the study showed that an average of $41 \%$ of the firms' capital was debt equity. The minimum was $12 \%$ and maximum was $72 \%$ within the study period.

\section{Correlation Matrix}

A correlation matrix is a table showing a correlation coefficient between set of variables. The correlation matrix between the variables in this study is shown in the table below.

Table 2: Correlation Matrix

\begin{tabular}{|l|l|l|l|l|l|l|l|}
\hline & SP & AUDFSZ & FEES & AUTEN & AUS & FS & LEV \\
\hline SP & 1.0000 & & & & & & \\
\hline AUDFSZ & 0.1530 & 1.0000 & & & & & \\
\hline FEES & -0.1102 & -0.1142 & 1.0000 & & & & \\
\hline AUTEN & 0.1081 & -0.1410 & 0.0579 & 1.0000 & & & \\
\hline AUS & 0.2219 & 0.2747 & 0.0345 & -0.0399 & 1.0000 & & \\
\hline FS & 0.0557 & 0.4403 & 0.0962 & 0.1087 & 0.1130 & 1.0000 & \\
\hline
\end{tabular}


International Journal of Social Science and Economic Research

ISSN: 2455-8834

Volume:05, Issue:12 "December 2020"

\begin{tabular}{|l|l|l|l|l|l|l|l|}
\hline LEV & -0.2210 & 0.1731 & 0.0365 & 0.2930 & 0.0015 & 0.3736 & 1.0000 \\
\hline
\end{tabular}

\section{SOURCE: STATA OUTPUT, 2019}

A correlation matrix shows the relationship between the independent and dependent variables and the independent variables among themselves. In this study, table 2 depicted that the coefficient of the relationship between shares price and audit firm size is $15 \%$. It means the use of Big4 audit firms leads to improvement in the shares price of banks. The table 2 also, showed an inverse relationship between audit fees and shares price. It means audit fees does not lead to improved market performance of banks. The relationship between audit tenure and shares price is $11 \%$ which means audit tenure influence market performance positively. The study also, showed a coefficient of 0.2219 for auditors' industry specialization and market price per share. Which means the longer an auditor stays on the job, the better the audit quality and ultimately an improvement in market performance. Table 2 evidenced that auditors' industry specialization relates with share prices with a coefficient 0.2219 . this implies that $22 \%$ of increase in shares price can be explained by industry specialist auditors. Shares price relates with firm size by $6 \%$ while leverage has a negative coefficient of -0.2210 . This means leverage cannot be used to explain the behavior of shares price of banks within the period covered by the study.

\section{Regression Diagnostics}

\section{Multi- collinearity Test}

In a regression analysis, it possible to have a case of auto correlation among variables. To avoid this situation a multi-collinearity test is suggested. Multi-collinearity is a state of very high intercorrelations or inter-associations among the independent variables. If this is present in data, the statistical inference made about the data may not be reliable.

\section{Variance Inflation Factor}

A variance inflation factor (VIF) identifies correlation between independent variables and the strength of that correlation. The table below shows the result of the variance inflation factor for this study.

Table 3: Variance Inflation Factor

\begin{tabular}{|l|l|l|}
\hline Variables & VIF & $1 / \mathrm{VIF}$ \\
\hline FS & 1.44 & 0.692349 \\
\hline
\end{tabular}


International Journal of Social Science and Economic Research

ISSN: 2455-8834

Volume:05, Issue:12 "December 2020"

\begin{tabular}{|l|l|l|}
\hline AUDFSZ & 1.44 & 0.694622 \\
\hline LEV & 1.27 & 0.789787 \\
\hline AUTEN & 1.15 & 0.868460 \\
\hline AUS & 1.09 & 0.917357 \\
\hline FEES & 1.05 & 0.955295 \\
\hline Mean VIF & 1.24 & \\
\hline
\end{tabular}

SOURCE: STATA OUTPUT, 2019.

The result of the variance inflation factor on table 3 showed absence of multi-collinearity. This is evidenced by the result of the mean variance inflation factor which is less than 10 and the tolerance level of greater than 0.05 for all variables.

\section{Test for Heteroskedasticity}

To use a regression analysis, certain assumptions must be met. One of the assumptions is that the data is homoscedastic. This means that the variance of the error term is consistent across all measures of the model. The Breuch-Pegan Test is the mostly used by researchers to determine statistically, whether data is heterosdastic in nature. The result of this test is shown below.

Breusch-Pagan / Cook-Weisberg test for heteroskedasticity

Ho: Constant variance

Variables: fitted values of SP

Chi2 $(1)=\quad 1.27$

Prob $>$ chi $2=\quad 0.0713$

For a study to be free from problem of hetreroskedasticity, the chi square probability of the result for Breusch-Pagan / Cook-Weisberg test for heteroscedasticity must be greater than 0.05. The result from the above table showed absence of the problem of heteroscedasticity. It means, the data were homogeneous in nature.

\section{Hausman Specification Test}




\section{International Journal of Social Science and Economic Research}

ISSN: 2455-8834

Volume:05, Issue:12 "December 2020"

This test is performed to detect endogenous repressors in a regression model. This is because endogenous variables have values that are determined by other variables in the system. This test is done with the aim of determining between fixed and random model which is more appropriate for the study. The result of the Hauseman specification test for this study is shown below.

Ho: difference in coefficients not systematic

$\operatorname{chi} 2(6)=(b-B)^{\prime}\left[\left(\mathrm{V} \_b-V \_B\right)^{\wedge}(-1)\right](b-B)$

$=0.42$

Prob $>$ chi $2=0.9987$

(V_b-V_B is not positive definite)

The result of the test showed a chi2 of 0.42 and a corresponding Prob>chi2 of 0.9987. The statistic rule is that when the p-value is greater 0.05 then random effect is more appropriate. Given that the probability is greater than 0.05, random effect is adopted and used for the analysis.

Table 4: Random Effect GLS Regression

\begin{tabular}{|l|l|l|l|l|}
\hline SP & COEF. & STD. ERR & Z & P>Z \\
\hline AUDFSZ & 0.0803515 & .0129489 & 6.21 & 0.000 \\
\hline FEES & -0.9068467 & .7071036 & -1.28 & 0.199 \\
\hline AUTEN & 3.009873 & 1.220897 & 2.47 & 0.014 \\
\hline AUS & .08233094 & .3226707 & 2.55 & 0.012 \\
\hline FS & 0.090371 & .4070578 & 0.22 & 0.824 \\
\hline LEV & -11.71403 & 4.217666 & -2.78 & 0.005 \\
\hline R-Square & 0.1281 & & & \\
\hline Wald chi2(6) & 17.12 & & & \\
\hline Prob > chi2 & 0.0089 & & & \\
\hline
\end{tabular}

SOURCE: STATA OUTPUT, 2019 


\section{International Journal of Social Science and Economic Research}

ISSN: $2455-8834$

Volume:05, Issue:12 "December 2020"

The R-square value showed the level at which the explanatory variables explain the dependent variable. Table 4 revealed an R-square of 0.1281 . This means that the audit quality variables in the study can be used to explained market price per share (MPS) to the tune of $13 \%$. The value of wald test is 17.12 with a corresponding probability of chi $2=0.008$. The probability of chi 2 is significant at $1 \%$, indicating that the model is fit. This serves as a substantial evidence to conclude that the audit quality variables selected for the study are suitable to explain the behavior of shares prices in the banking industry.

The table 4 also, showed that audit firm size has a coefficient of 0.0803 with a corresponding pvalue of 0.000 which indicates that $8 \%$ of the behavior of shares prices can be explained using the size of auditors and this significant as evidenced by the P-value. This shows that audit firm size has a positive and significant effect on market price per share of DBMs in Nigeria. On this basis, the study rejects the null hypothesis which states that audit firm size has no significant effect on market performance of quoted deposit money banks in Nigeria.

The result of the study again, showed that audit fees have a negative coefficient of -0.9068 and a p-value of 0.199. This depicts a negative and insignificant effect on market price per share of quoted DBMs in Nigeria. This implies the audit fees cannot be used to explain the variations behaviour of shares price of DBMs in Nigeria. On this bases we accept the null hypothesis which states that audit fees have no significant effect Market performance of quoted deposit money banks in Nigeria.

Tables 4 indicated that audit tenure has a coefficient of 3.0098 and a p-value of 0.014 which imply that the tenure of an auditor can be used to predict the movement of shares prices of quoted DBMs in Nigeria. That audit tenure has a positive and significant effect on market performance of quoted DBMs in Nigeria as evidenced by the value of the coefficient and the $\mathrm{p}-$ value. On this note, the study rejects the null hypothesis which states that audit tenure has no significant effect on market performance of quoted DBMs in Nigeria.

The study also, showed that auditors industry specialization has a positive and significant effect on market price per share of quoted DBMs in Nigeria. This is evidenced by a coefficient of 0.0823 and a P-value of 0.012 signifying that more industry specialist auditors engaged by the banks the better their market performance. Given the significant p-value, the study rejects the null hypothesis which states that auditors' industry specialization has no significant effect on market performance of quoted deposit money banks in Nigeria.

The study controlled for firm size and leverage and the result on table 4 showed that firm size has a positive insignificant effect on market performance of banks in Nigeria while leverage has a negative but positive on market performance of quoted DBMs in Nigeria. 
International Journal of Social Science and Economic Research

ISSN: 2455-8834

Volume:05, Issue:12 "December 2020"

\section{CONCLUSION AND RECOMMENDATION}

\section{Conclusion}

The study examined the effect of audit quality on market performance of quoted deposit money banks in Nigeria. Specifically, the study examined the combined effects of audit firm size, audit fees, audit tenure and auditors' industry specialization on market performance (explained by market price per share) of quoted deposit money banks in Nigeria. Based onthe findings and statistical evidence, the study concluded that audit firm size, audit tenure and auditor industry specialization exert significant influence on market performance of quoted deposit money banks in Nigeria. This means that these variables can be used to explain and predict the bahviour of shares price in the Nigerian banking sector. On the other hand, the study concluded that audit fees do not exercise any influence on market performance of quoted deposit money banks in Nigeria. This is because the study lacks statistical evidence to conclude that audit fees have any impact on market performance of banks in Nigeria.

\section{Recommendations}

The study provided empirical evidence supporting that audit firm size, auditor tenure and auditor industry specialization comes across as highly significant components that have striking implications on the likelihood of market performance of quoted deposit money banks in Nigeria. The study recommends that the benefits of longer auditor tenure should be considered, the possibility of the Big4 in using their resources and expertise in arresting management misrepresentation should be considered, also, the experience and expertise of industry specialist auditors should be considered in deciding the nature of auditors to be engaged by banks in Nigeria.

\section{References}

Adeyemi, S. B. and Fagbemi, T. O. (2010). Audit quality, corporate governance and firm characteristics in Nigeria, International Journal of Business and Management, 5 (5), 169 -179 .

Alles, M. G., Kogan, A. and Vasarhelyi, M. A. (2004). Restoring auditor credibility: tertiary monitoring and logging of continuous systems, International Journal of Accounting Information Systems, 5, $183-202$.

Ebrahim, A. (2001). Auditing quality, auditor tenure, client importance, and earnings management: an additional evidence, Unpublished, Rutgers University.

Ali, A. (1994). Incremental information content of earnings, working capital from operations, and cash flows, Journal of Accounting Research; 32, 61-74. 


\section{International Journal of Social Science and Economic Research}

ISSN: $2455-8834$

Volume:05, Issue:12 "December 2020"

Amir, E. (1996). The effect of accounting aggregation on the value - relevance of financial disclosures: The Case of SFAS No. 106. The Accounting Review, 71, 573 - 590.

Amir, E. and Lev, B.(1996). Value - relevance of nonfinancial information: the wireless communication Industry, Journal of Accounting and economics, 22, 3 - 30.

Arrunada, B. (2000). Audit quality: attributes, private safeguards and the role of regulations. The European Accounting Review, 9 (2), 205 - 225.

Badawi, I. M. (2008). Motives and consequences of fraudulent financial reporting. paper presented at the $17^{\text {th }}$ annual convention of the global awareness society international, May, 2008, San Fracisco, USA.

Beneish, M. D. (1997). Detecting GAAP violations: implications for assessing earnings management among firms with extreme financial performance, Journal of Accoun ting and Public policy, 16, $271-309$.

Beneish, M. D. and Vargus, M. E. (2002). Insider trading, earnings quality, and accrual mispricing, The Accounting Review, 4, 755 - 791. Bergstresser, D. and Philippon, T. (2002). Manager incentives and earnings management. Journal of Financial Economics.

Bowen, R, Burgstahler, D. and Daley, L. (1987). Incremental information content of accrual versus cash flow. The Accounting Review, 62, 723 - 47.

Burgstahler, D. C., and Dichow, I. D. (1997). Earnings management to avoid losses and earnings decreases. Journal of Accounting and Economics, 24, 99 - 126.

Burns, N. and S. Kedia (2004). The impact of performance-based compensation on misreporting", Mimeo HBS Carmichael, D. R. (2004). The PCAOB and the social responsibility of auditors, Accounting Hrrizons, 18 (2), 127 - 133.

Chan, K, L. Jegadeesh, N. and Lakonishok, J. (2001). Earnings quality and stock returns, Working Paper, National Bureau of Economic Research.

Chariton, A. and Ketz. J. (1990). Valuation of earnings, cash flows and their components: an empirical investigation, Journal of Accounting, Auditing, and Finance, 5, 75 - 497.

Clarkson and, P. M. and Simunic, D. A. (1994). The association between audit quality, retained ownership and firm specific risk in U.S. vs. Canadian IPO markets, Journal of Accounting and Economics, 17, $207-228$.

Craswel, A., Stokes, D. J. and Laughton, J. (2002). Auditor independence and fee independence, Journal of Accounting and Economics, 33, 253 - 275. 


\section{International Journal of Social Science and Economic Research}

ISSN: $2455-8834$

Volume:05, Issue:12 "December 2020"

Davidson, R. A. and Neu, D. (1993). A note on association between audit firm size and audit quality, Contemporary Accounting Research, 9 (2), 479 - 488.

DeAngelo, L. E. (1981). Auditor size and audit quality, Journal of Accounting and Economics, 3 (3), $183-199$.

Dechow, P., Sloan, R. and Sweeney, A. (1995). Causes and consequences of earnings manipulations: an analysis of firm's subject to enforcement actions by SEC, Contemporary Accounting Research, 13, 1 - 36.

Deis, D. R. and Giroux, G. A. (1992). Determinants of audit quality in the public sector, the Accounting Review 67 (3), 462 - 479. Dye, R. (1988). Earnings management in an overlapping generations model, Journal of Accounting Research, 26, 195-235.

Eilifsen, A. and Messier, W. F. (2000). The incidence and detection of misstatements: a review and integration of archival research, Journal of Accounting Literature, 19, 1 - 43.

Enofe, A. (2010). Reaping the fruits of evils: how scandals help reshape the accounting profession, International Journal of Business, Accounting and Finance, 4 (2), 53 - 69.

Federal Republic of Nigeria (2011).: Financial Reporting Council Act, No. 54, $\left(7^{\text {th }}\right.$ June) (98); Government Notice No. 140, The Federal Government Printer, Lagos, Nigeria.

Francis, J. R. and Krishnan, J. (1999). Accounting accruals and auditor reporting conservatism, Contemporary Accounting Research, 16 (1), 135 - 65

Frankel, R., Johnson, M. and Nelson, K. (2002). The relation between auditors' fees for nonaudit services and earnings quality, The Accounting Review 77 (Supplement), 71-105.

Gerayli, M. S., Yanesari, A. M. and Ma'atoofi, A. R. (2011). Impact of audit quality on earnings management: Evidence from Iran, International Research Journal of Finance and Economics, 66, http//www.eurojournals.com/finance Retrieved February 27, 2010

Healy, P. M., and Wahlen, J. M (1999). A review of the earnings management literature and its implications for standard setting, Accounting Horizons, 13, 365 - 383.

Heninger, W. G. (2001).The association between auditor litigation and abnormal accruals, The Accounting Review, 76 (1), $111-126$.

Kedia, S. and Philippon, T. (2008). The economics of fraudulent accounting, Review of Financial Studies.

Khan, T. (2006). Financial reporting disclosures: an international perspective (Unpublished), Victoria University, Australia. 
International Journal of Social Science and Economic Research

ISSN: 2455-8834

Volume:05, Issue:12 "December 2020"

Kim, J., Chung, R. and Firth, M. (2003). Auditor conservatism, asymmetric monitoring and earnings management, Contemporary Accounting Research, 20 (2), 323 - 359.

Knechel, W. R. (2009). Audit lessons from the economic crisis: rethinking audit quality. inaugural lecture delivered at Maastricht University on Friday, September 11.

Krishnan, G. V. (2003). Does Big 6 auditor industry expertise constrain earnings management? Accounting Horizons, 17 (Supplement), 1 - 15

Krishnan, J. and Schauer, P. C. (2000). The differentiation of quality among auditors: evidence from the not- for-profit sector, Auditing: A Journal of Practice and Theory. 19 (2), 9 - 26.

Krishnan, J. and Yang, J. S. (1999). Auditor industry specialization and earnings response coEfficient, working paper. Temple University, (April).

Lennox, G. S. (1999). Audit quality and auditor size: an evaluation of reputation and deep pocket hypotheses, Journal of Business Finance and Accounting, 26 (7/8): 779 - 805.

Lev, B. (1989). On the usefulness of earnings and earnings research: lessons and directions from two decades of empirical research, Journal of Accounting Research, 27 (Supplement), $153-201$.

Levitt, A. (1998). The numbers game: speech delivered at the New York University center for law and business, New York. http://wwwrutgers.edu/accounting; http://www.sec.gbov/news

Li, J. and Lin, J. (2005). The relationship between earnings management and audit quality, Journal of Accounting and Finance Research, 12 (1), 1- 11.

Limperg Institute, (1985). The social responsibility of auditors: a basic theory on auditors function. The Limperg Institute, Netherlands.

Livnat, J. and Zarowin, P. (1990). The incremental information content of cash-flow components, Journal of Accounting and Economics, 12, 25 - 46.

Mautz, R. K. and Sharaf, H. A. (1961). The philosophy of auditing; Florida, American Accounting, Association, Monograph Series (6).

McNichols, M. and Stephen Stubben, (2008). Does earnings management affect firms' investment decisions, The Accounting Review,

Moizer, P. (1997). Auditor reputation: the international empirical evidence, International Journal of Auditing, 1 (1), 61 - 74. 
International Journal of Social Science and Economic Research

ISSN: 2455-8834

Volume:05, Issue:12 "December 2020"

Odia, J. (2007). Creative accounting and its implications for financial reporting in Nigeria. Nigeria ournal of Business Administration, 8 (1 \& 2) (Jan/July).

Ahmadi, M., (2009), The Effect of Audit Quality on Earnings Predictability. Master's Thesis. ShahidBeheshti University.

Ansari A., et al., (2009), Examining the Effect of Internal Audit Variables on the Audit Programs. Study of Accounting and Auditing.

Azinfar, K., (2007). The Relationship between Audit Quality and Auditor Size. Master's Thesis. AllamehTabatabai University.

Bauwhede, HV, Marleen Willekens.(2004). Evidence on (the lack of) Audit - quality. Differentiation in the Private Client Segment of the Belgian Audit Market; European Accounting Review, 13(3), 501-522.

Deltas, G, Doogar, R. (2004). Product and Cost Differentiation by Large Audit Firms, 110.Fuerman, R. (2006) Comparing the Auditor Quality of Arthur Andersen to that of the Big 4: API,6, 1-10.

Givoly, D.C. Hayn\& A. Natarajan (2007). Measuring Reporting Conservatism, The AccountingReview.

Gul, Ferdinand. Bikki L, Jaggi. Gopal ,V. Krishnan. (2007). Auditor Independence: Evidence on the Joint Effects of Auditor Tenure and Nonaudit Fees. Auditing: A Journal of Practice \& Theory, 26(2), 117-142.

Hassas Yeganeh, Y., (2005), Audit Philosophy. ElmivaFarhangi Tehran Publishing.

Hassas Yeganeh, Y., et al., (2010), The Relationship between Audit Firm Size and Audit Quality,

Journal of Accounting and Auditing, Volume 1, Issue 61, pp. 85-98

Henock Louis. Acquirers Abnormal Returns, Audit Firm Size and the Small Auditor Clientele Effect, Journal of accounting and economics 2005. 


\section{International Journal of Social Science and Economic Research}

ISSN: $2455-8834$

Volume:05, Issue:12 "December 2020"

Jafari, Ali, (2006). Affecting Factors on Audit Quality. Doctoral dissertation. AllamehTabatabai University.

Lafond, R. and R. Watts(2008), The Information Role Conservative Financial Statement.

Namazi, Mohammad, et al. (2010). Examining the Relationship between Earnings Management and Audit Quality. Research in Accounting and Auditing, 2(9), 22-4

NezamiArdakani, M. (2009). Auditor's Industry Specialization and Earnings Management. Master'sthesis. Department of Economics.

Givoly, D.C. Hayn\& A. Natarajan (2007). MeasuringReporting Conservatism, The Accounting Review.

Gul, Ferdinand. Bikki L, Jaggi. Gopal ,V. Krishnan. (2007). Auditor Independence: Evidence onthe Joint Effects of Auditor Tenure and Nonaudit Fees. Auditing: A Journal of Practice \& Theory,26(2), 117-142.

Hassas Yeganeh, Y., (2005), Audit Philosophy. ElmivaFarhangi Tehran Publishing.

Hassas Yeganeh, Y., et al., (2010), The Relationship between Audit Firm Size and Audit Quality,

Journal of Accounting and Auditing, Volume 1, Issue 61, pp. 85-98 Henock Louis. Acquirers Abnormal Returns, Audit Firm Size and the Small Auditor Clientele Effect, Journal of accounting and economics2005.

Jafari, Ali, (2006). Affecting Factors on Audit Quality. Doctoral dissertation. AllamehTabatabai University.

Lafond, R. and R. Watts(2008), The Information Role Conservative Financial Statement.

Namazi, Mohammad, et al. (2010). Examining the Relationship between Earnings Management and Audit Quality. Research in Accountingand Auditing, 2(9), 22-4

NezamiArdakani, M. (2009). Auditor's Industry Specializationand Earnings Management. Master'sthesis. Department of Economics. 
International Journal of Social Science and Economic Research

ISSN: 2455-8834

Volume:05, Issue:12 "December 2020"

Nounahal, A. A. et al. (2010). The Relationship betweenAudit Quality and Reliability of Accruals.Examining Accounting and Auditing, 17(61),55-70

Seyyedi, S. A. (2008), The Role of IndependentAuditors in Reducing Earnings Management.Master's thesis. AllamehTabatabaiUniversity

Shabahang, R. (2002), Accounting Theory 1, Accountingand Auditing Corporate Audit Center

Titman, S. B, Trueman. (1986). Information Qualityand the Valuation of New Issues. Journalof Accounting Research, 26,127-132

Zhou, Jian and Randal, Elder. (2004). Audit Qualityand Earnings Management by Seasoned EquityOffering Firms. Asia-Pacific Journal of Accountingand Economics, 11(2), 95-120. 